Collection: 3rd International Elm Conference, Florence (Italy - 2013)

"The elms after 100 years of Dutch Elm disease"

Guest Editors: A. Santini, L. Ghelardini, E. Collin, A. Solla, J. Brunet, M. Faccoli, A. Scala, S. De Vries, J. Buiteveld

\title{
The elm, tree of milk and wine
}

\author{
Hans M Heybroek ${ }^{(1-2)}$
}

Elm has played an important role in European culture for thousands of years, in many roles, with regional variation. In material culture, its wood has assisted in hunting and warfare for over seven thousand years; but more importantly, its leaves and bark were semi-indispensable for the production of milk and meat, and served as an emergency food for humans. In the Mediterranean, elm was the main tool for the production of a good quality wine by providing support for the grapevine, and it helped feeding the cattle. These functions sometimes found an echo in the non-material culture. The fact that in Germanic genesis stories the first woman was created out of an elm (the man out of an ash), as well as a severe local taboo on the use of elm wood for skis, threatening the offender with a place in hell, seem both connected to the superior feeding value of this tree. In England and in parts of continental Europe most sacred trees were elms, sometimes performing female functions such as the production of babies. In the Mediterranean, however, the elm was seen as the male partner in the "marriage of the vine to the elm", which was the celebrated system of viticulture. That image has been used by poets and politicians over the ages to praise the effects of human marriage, cooperation and interdependence. It even forms the core of the apocryphal Bible book "The Shepherd", where it is seen as a symbol and example for a kind of symbiosis between the rich and the poor. In conclusion, the ultimate origin of the English elm or "Atinia", as well as its discovery is discussed, which appears to be a question of milk and wine.

Keywords: Ulmus, Viticulture, Fodder, Emergency Food, Non-material Culture, Cultivar "Atinia", Cultivar "Arbia"

\section{The elm, tree of milk and wine}

The story I am going to tell started in the Himalaya in 1960. In the preceding years I had tried to collect additional basic material for our elm breeding project which was started back in 1927 by Christine Buisman, continued after her death in 1936 by Johanna Went, from whom I took it over in 1953. I collected budwood from good-looking sur-

(1) Formerly at Dorschkamp Forest Research Station, Wageningen (The Netherlands); (2) Current address: Jonkerlaan 90113, 2242 EX Wassenaar (The Netherlands)

(a) Hans M Heybroek (hmheybroek@tiscali.nl)

Received: Jan 16, 2014 - Accepted: Jul 17, 2014

Citation: Heybroek HM, 2015. The elm, tree of milk and wine. iForest 8: 181-186 [online 2014-08-13] URL: http://www.sisef.it/ iforest/contents/?id=ifor1244-007

Communicated by: Alberto Santini viving elms mainly in France, England, Ireland and Holland, hoping some might have a useful degree of resistance to the disease but also resistance to sea wind, which we need in our elms. Thereby we got experience in sending budwood home by mail in fall and having it grafted in the greenhouse. Getting budwood by correspondence was not successful. So, when our single clone of Ulmus wallichiana was badly damaged in the severe winter of 1955/56, our Elm Committee decided I should go to the Himalaya myself and select good types (good shape, frost resistance, hopefully even higher resistance to disease) of $U$. wallichiana there. The species played a pivotal role in our breeding: we had many small-leaved clones of $U$. minor with a reasonable level of disease resistance, which we wanted to combine with a resistant largeleaved clone, so repeating the success story of $U . x$ hollandica. But the large-leaved $U$. glabra was uniformly very susceptible, and so was U. elliptica, its relative from the Caucasus; the only remaining candidate with an acceptable level of resistance was $U$. wallichiana, whose morphology and ecology are more or less comparable to U. glabra. A wider range of genotypes of that species from the colder valleys of the Himalaya seemed desirable.

So, after extensive preparations, I found myself in beautiful Kashmir, in the foothills of the Himalaya, in August 1960. The valley of Kashmir, with its large lakes, lies at some $1600 \mathrm{~m}$ a.s.l.; as $U$. wallichiana occurs roughly at altitudes of between 1800 and $3000 \mathrm{~m}$, we had to ascend into the surrounding hills. The Indian Forest Service, and the Botanical Survey of India provided liberal assistance. Soon, in a mixed coniferous forest that looked like our alpine forests, we found our first $U$. wallichiana. What a disappointment! It was a crooked stump, with hardly any branches or twigs. I had come here hoping to find trees with a good shape for Dutch conditions, not expecting monstrosities like this one. Fortunately, in the following days, the story behind this tree unfolded. We found another elm, what a relief, this time a well-grown middle-aged tree indeed, but with some damage in the crown. There was a shepherd with his sheep around, my companions asked him something, he agreed, went to the elm, put a small longshafted axe in his belt, took his shoes off and climbed bare-footed rapidly into the crown of the tree. There he started cutting twigs with leaves and threw those down. I was happy, as I could choose and cut good budwood, put it in polythene and wrap the bag in a wet cloth to keep it cool. But the shepherd did it to give his sheep good fodder: they came and ate the leaves eagerly. The shepherd was on his way to lower elevations, end-summer in the annual vertical trek, which we call transhumance in Europe. On his way down through this valley, passing through the semi-public forest he would lop elms as their leaves were an excellent fodder. If the tree was ruined in the process, he would scarcely care. It was a destructive way of lopping. We saw more of such elms on our way: if you want to be a shepherd here, you must be able to climb trees! (Fig. 1).

But the story goes on. We also often saw elms, mostly close to habitation or between fields, which were carefully lopped (Fig. 2), while the cut twigs were stored orderly in a fork. These twigs would be collected in winter by the owner of the tree and serve as a rich winter fodder for the animals, next to straw of corn and other poor foodstuff. Hay seemed not to be present. So, besides the fatal overuse of the elms by the shepherds, there was a sustainable use by the sedentary farmers, they even planted elms solely for this purpose. We passed by a farmhouse where three young trees had been planted recently: a peach, an almond and an elm. We asked the farmer why he had chosen these three species (silly questions these foreigners 


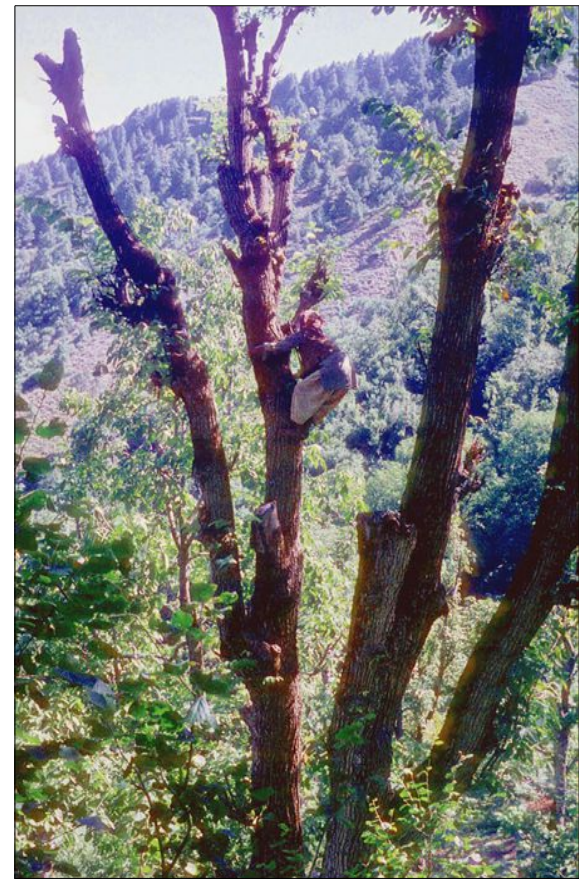

Fig. 1 - The shepherd climbing on an elm for destructive lopping.

Fig. 2 - Sustainable use of elm: the tree on the left has been lopped very carefully; the others will follow.

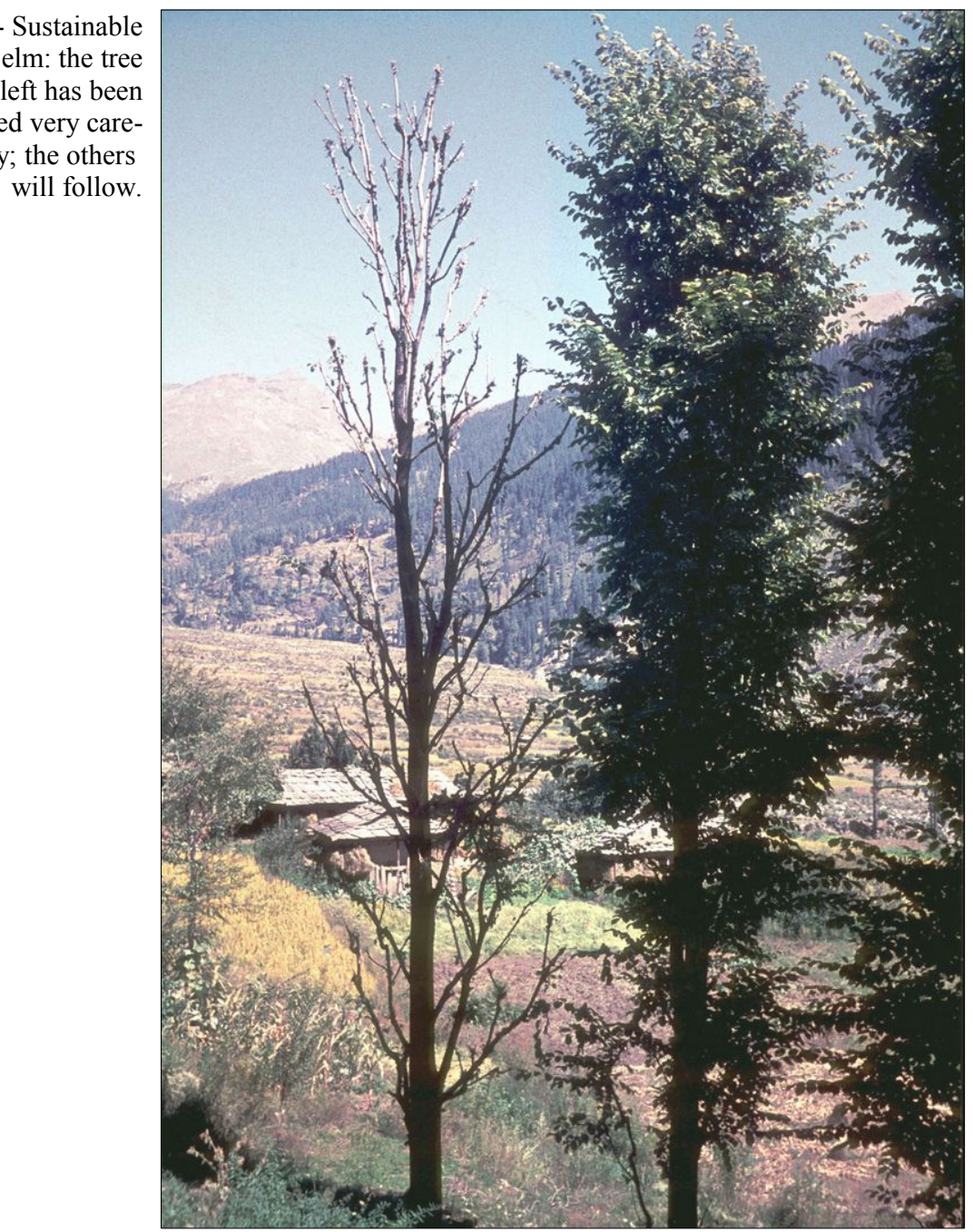

can ask!): "Well, obviously, the fruit trees for the humans, the elm for the cow". We saw one village surrounded by a row of planted elms (Heybroek 1963). But both the destructive lopping in the forest and the sustainable lopping by the farmers would prevent the trees from flowering, preventing natural regeneration. Occasionally, some other tree species was lopped for fodder. One specimen of ash (Fraxinus sp.) was seen, it was lopped.

Back in Europe, I found to my surprise that there is a solid body of literature on the use of tree leaves for fodder here too, both in the distant and in the near past. In some regions this use exists even today.

First the distant past. In archeology, there is a continuing discussion on the so-called elm decline, a widespread and severe reduction of the presence of elm pollen in European pollen diagrams of about 6000 years ago over a large part of the continent. As this coincided more or less with the immigration of new groups of farmers, scientists suggested these farmers kept their cattle mainly in kraals close to habitation, and fed them with lopped tree twigs and leaves (Troels-Smith 1960). Preferred tree species were elm and ash, perhaps with lime and rowan at the side. Other tree species were less or not edible. Young and inner bark of elm may have been used as a very good fodder for pigs and horses, even for calves and in emergency as food for humans.

Discussions continue on the question how much impact this human use of elm might have had on the elm population of those days, and in how far it could explain or have contributed to the reduction of elm pollen in the diagrams. After all, the human population was perhaps too low to explain it all by itself. Some scientists have therefore suggested a hypothetical disease that might have reduced the elm population; elsewhere, I have argued that the human uses of elm may have started local outbreaks of elm bark beetles which by their sheer numbers killed weakened and old trees, perpetuating the outbreak over a number of years until it was smothered by a wet and cool summer (Heybroek et al. 2009).

But all speculations on the prehistoric human use of elms are based on well-documented historical cases of such use. These are overwhelming, and one may assume that our forebears knew all survival tricks based on leaves and bark that Machatscheck (2002) describes for the farmers in the Alps and the Balkan. Leaf fodder in general was an essential element in husbandry in large parts of Europe, lately still in Scandinavia, in the Alps and in the Balkan. Lopping the trees for leaf hay was done with a traditional kind of knife, the Gertel (Fig. 3). Traditional farmhouses in Switzerland had a Laube, a room open to the outside but well protected against rain, where the leaf hay or Laub was stored. The Swiss family name Lauber apparently goes back to a person or family that was particularly good in lauben, lopping for fodder. Elm and ash were the favorite species, but it was elm that got the highest praise. Elm leaf hay had the highest nutritional value, "better than the best hay", "as the best lucerne-hay", "as barley flour" (Pässler 1893, Petrovic 1936, Woodman 1945, Russell 1947, Trier 1963, Haas \& Rasmussen 1993, Machatscheck 2002). It was even used to fatten pigs. It was a very healthy food, good for the teeth of the animals, and it would give a good taste to butter and milk, while ash leaves could cause a rancid taste. Domestic animals are not the only customers; many animals in the zoo, including elephants and giraffes, appreciate elm leaves as a delicacy. Young shoots were cooked and eaten as vegetables by humans, and meal of elm leaves was an emergency food in various regions (Brockmann-Jerosch 1936).

The living layers of the bark, that is bark of young parts of the tree and the inner bark of older and corky parts, are very nutritious too. Horses and pigs are fond of it, and can badly damage or kill elm trees by debarking them. 
Voles, rabbits, hare, goats and sheep can likewise girdle and kill elms. Chopped or shaven bark was given to the cows in Norway, while the slime that could be extracted in water from it was given to young calves. But there was an even more valuable use for elm bark, it could save lives: in years of famine, a good quality bread could be baked with the inner bark of elms. Fishermen sailed deep into the fjords to barter their best fish against elm bark (Landmark 1863, Nordhagen 1954, Ropeid 1960). Therefore, an elm could serve as a wedding gift, even the usufruct could do. Elms were planted as a fruit tree. Elm was the life-saving Nordens Brødfrugttrce (Ropeid 1960), so some old elms were seen as sacred trees, and there was a taboo on its cutting. Elm wood was technically perfect for skis, but if you had a fatal accident on such skis, you would not be buried in consecrated earth - as you had gone straight to hell already (Hoeg 1953).

The elm had some additional functions in European culture, which I want to mention shortly.

The fibers of elm bark could be made into strong cords; as these were used for beehives, for well-cords and in thatching, they could apparently withstand dry-wet conditions. In eastern Europe, foot wear and mats were made of them; in the XIX century, millions of such elm mats were exported to western Europe annually. The Ainu people in northern Japan traditionally made very durable clothes of elm bark: they peeled the bark off the trees in spring or fall, then soaked it in water for ten days, divided it in strips which could be used for weaving. This textile could be colored dark with oak bark or with iron-containing peat, creating bold traditional patterns (Fig. 4). But there are no indications that our European ancestors ever used clothing from bark.

Elm wood has been important in warfare. For both hunting and warfare, bow-and-arrow have been essential tools for many thousands of years. The very best wood for making bows came from the yew tree, but, when that one was not available or scarce, elm was the second best choice. Such was the case in the whole of northern Europe, where the yew, in its trek to the north, arrived late: in Scandinavia, elm was the standard bow for millennia. In the Middle Ages, when the longbow was popular and the yew scarce, elm was recommended as a replacement, to stretch the stock of yew. Later still, shock-resistant elm wood was very much in demand by the military for gun carriages and other equipment; that is why several French kings, but also the French Revolution launched campaigns exhorting people to plant elms.

\section{Non-material culture}

In the old Germanic mythology, the first

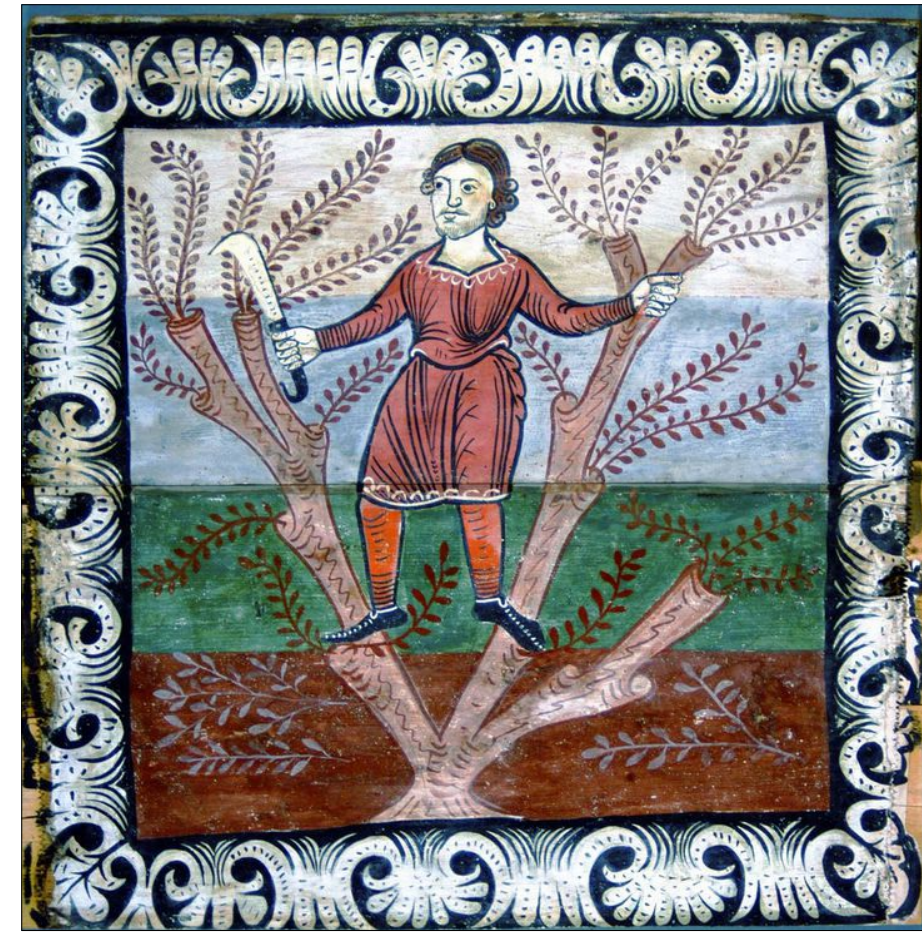

Fig. 3 - Lopping of elm in Switzerland (church in Zillis, Graubünden, ca. 1110). living creature was apparently the cow "Audumbla", who freed the first giant Ymir out of the ice and fed him with her milk; later, she also liberated the giant Buri, who would become the progenitor of the gods. It shows how important the cow was for the people who created the mythology: the gods could only come into being thanks to the cow! Humans originated later, thanks to an action of the gods: one day, when the god Odin with his two brothers, sons of Buri, walked along the shore, they found two tree trunks, Askr and Embla, that is ash and elm. Out of these they fashioned man and woman, the man out of Askr, the woman out of Embla. Here rises the question: why these two trees? In mythologies it is not unusual that trees change into humans or vice versa, but why here these two species, why ash and elm? It can be no accident that it was this twosome, ash and elm, that produced the essential fodder for the all-important cow, and the cow was the basis for human existence and culture. After all, food is life. So, human life depended on ash and elm. Out of that couple, the elm, being the most nutritive, represented the woman, while the ash, that contributed also the spear, stood for the man.

Therefore, the elm has kept a female image up to recent times. The hollow elm at the garden restaurant of Kraantje Lek, near Haarlem (The Netherlands), as well as the old "Luther elm" near Worms (Germany), were reputed locally to be the places where

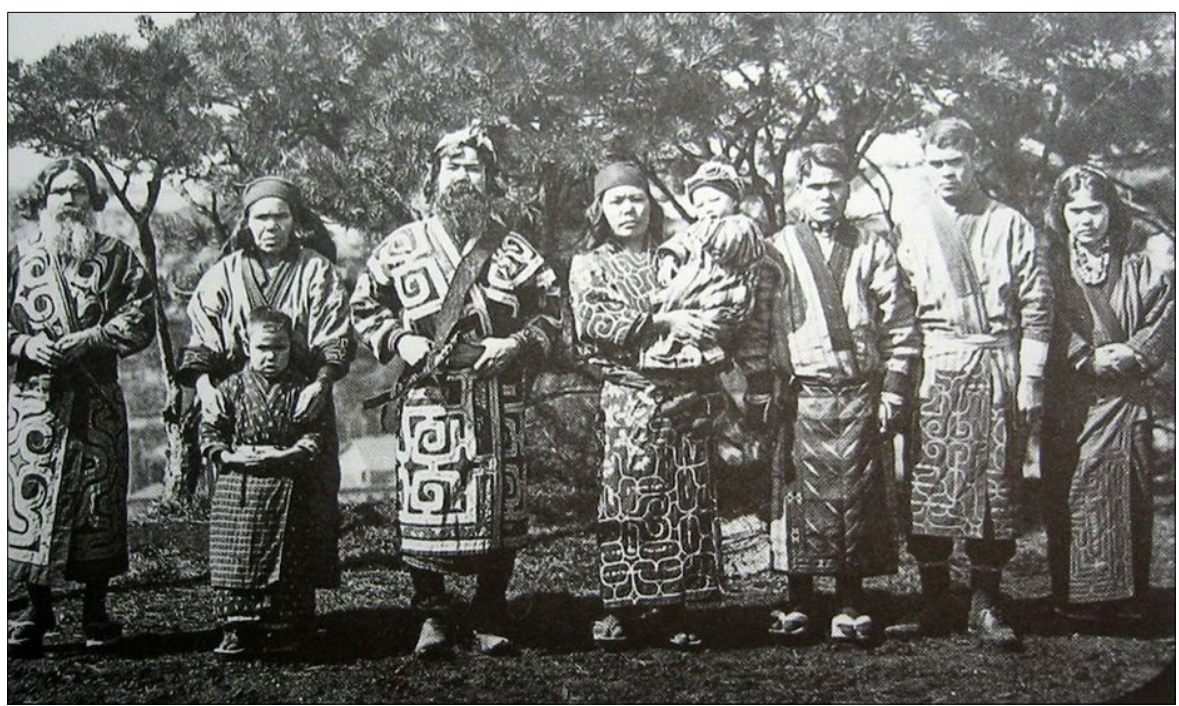

Fig. 4 - A group of Ainu people wearing the traditional dress made from elm bark. 


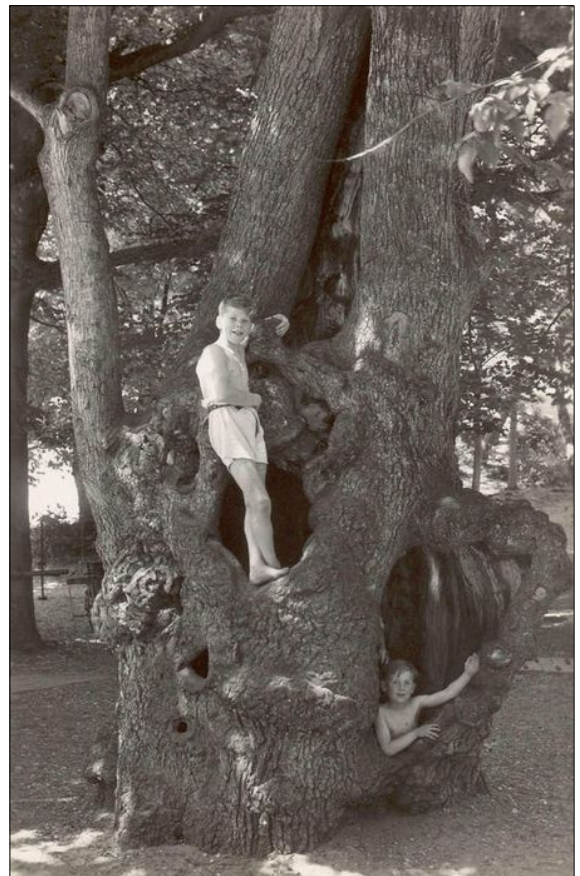

Fig. 5 - The famous "hollow elm" at the "Kraantje Lek", garden restaurant near Haar-

the dry nurses fetched the babies (Fig. 5). Male fertility, on the other hand, was promoted by an old ash at Spaarndam at the eastern side of Haarlem. Napoleon had wanted a son for years in vain; he got one only after he had slept one night under this magic ash; at least, so the local wisdom tells us. Even the Vikings identified still with the ash: they called themselves askmannen, that lem (Netherlands); postcard, ca. 1930.

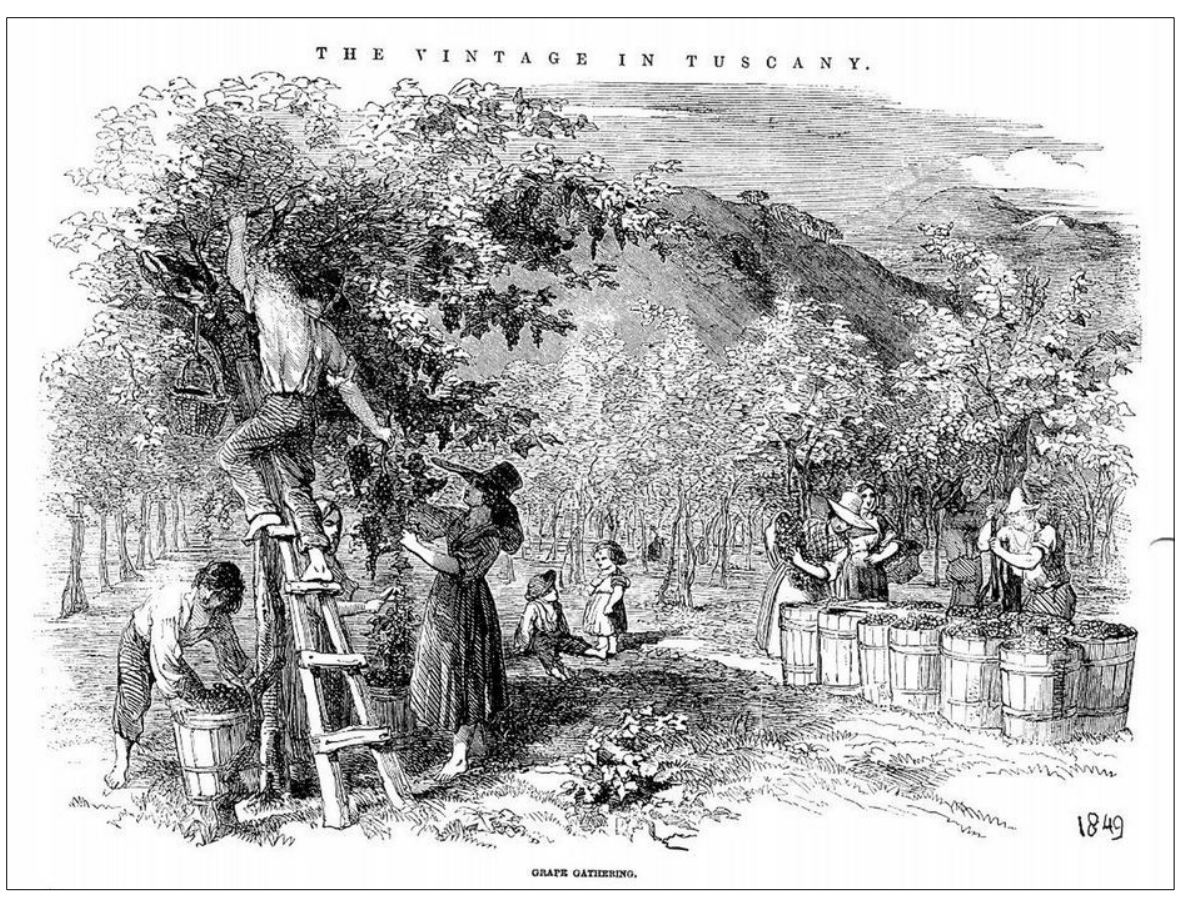

Fig. 6 - Grape harvest in Tuscany, 1849. is, men of the ash, i.e., of Askr, but also of the ash Yggdrasil, the Germanic world tree (De Vries 1961).

In addition to the ones mentioned, elm has had some other functions, but the most important one, from deep prehistory until recently, was the provision of fodder for the cattle, producing milk and associated products.

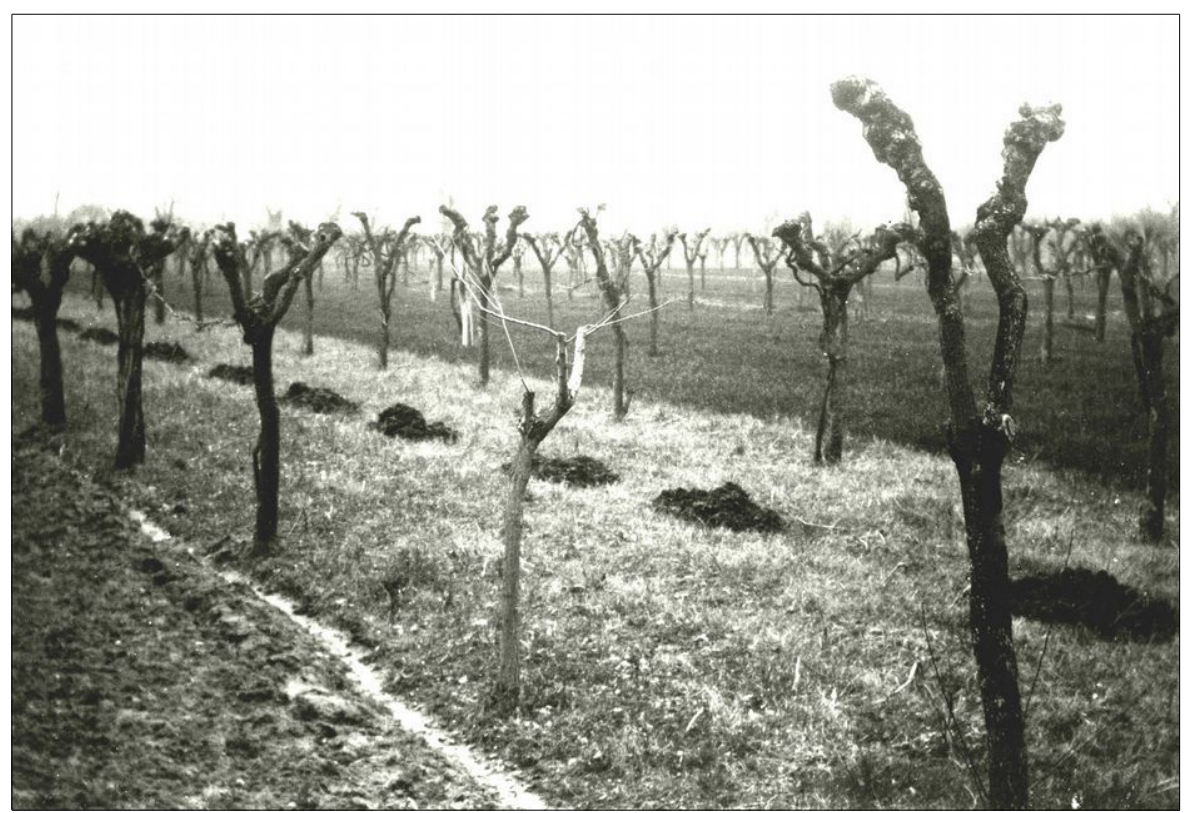

Fig. 7 - Coltura promiscua in Emilia: rows of lopped elms (one dead by DED) as props for the grapevine, heaps of manure for the field crops (lucerne for the cattle, and grain) between them (Photo: C. Buisman, 1935).

\section{The Mediterranean}

In the Mediterranean, however, things were different: the elm had a decidedly male image here. That was based on viticulture. Plinius wrote: "Since very old times, the judgment is accepted that excellent wines grow on trees only". The opinion was that the best and tastiest wine, which keeps well, can be made from grapes that have grown high above ground, up in trees. This opinion goes probably back as far as $600 \mathrm{BC}$ in Greece, when "tree-vines" (ámpelos ánadendras) started to be mentioned in Greek literature (Hagonow 1972 - we do not know details as all old Greek treatises on agriculture have gone lost - Fig. 6 and Fig. 7). So, farmers planted trees in which they trained the grapevines. Several tree species could serve in this function, but elm was the favorite. Columella, a Spanish Roman citizen, gave a full description and manual for this kind of viticulture in his treatise De Re Rustica. Incerti autoris: Liber de arboribus, around 50 AD. Sowing, growing, planting and care of the elms was described in detail. The common field elm could be propagated by seed, the Gallic elm or atinia, however, which he preferred, produced no viable seed and had to be propagated vegetatively. This atinian elm was preferred by the sheep too: if they had eaten its leaves, they refused to accept the field elm! (Columella, around $50 \mathrm{AD}$ ). In probably all countries where the Romans introduced their viticulture they also imported this atinian elm: in Spain and Portugal, in Switzerland and Germany as well as in Eng- 


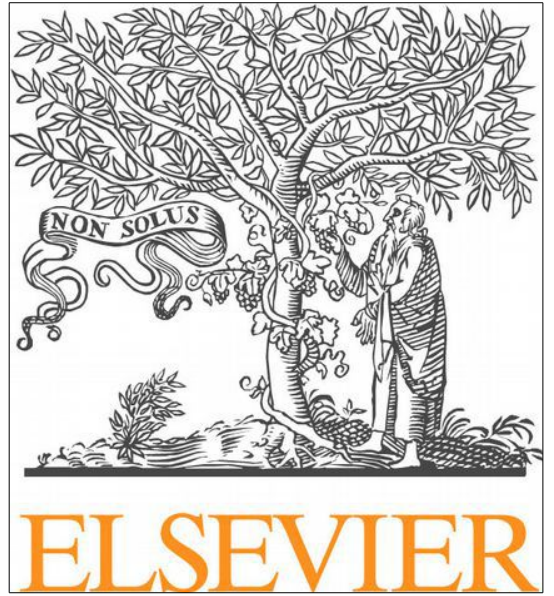

Fig. 8 - The old Elsevier logo, showing an old wise man that earns the fruits of cooperation of elm and grapevine.

land. In the latter country it was planted large-scale in the succeeding centuries after the Romans left, and, forgetting its Roman origin, people called it "English elm". Nowadays we consider it to be a very old cultivar (Gil et al. 2004) which merits a cultivar name; the logical one is "Atinia". Curiously, it has not yet been authenticated in Italy, nor in France, Romania, Greece or Turkey, but that may be a question of time and looking at the right places. I will come back to this later.

Let us first look at the impact a simple agricultural practice has made in the non-material culture (Fuentes-Utrilla et al. 2004). The Roman farmers used to call their practice to lead the vines into the elm as "marrying the grapevine to the elm". This saying was taken up gratefully by the poets Vergil and Catullus as a metaphor for the human marriage: "the elm ( the man) is strong and grows high and wide, but it is sterile, it bears no real fruits; the vine ( $\sim$ the woman) on the other hand, is weak, by itself it would have to crawl over the ground where its fruits would rot and decay. But combined in marriage, the vine would grow high into the light and together they would produce ample healthy fruit ( offspring)". This metaphor was widely known and used; even Shakespeare used it, 1600 years later. His Adriana wanting her husband to come back, says to the man whom she takes for him: "You are an elm, my lord, I a grapevine". The meaning of the symbol was also broadened to friendship, cooperation, interdependence. The beautiful old logo of Elsevier shows an old wise man that earns the fruits of cooperation of elm and grapevine (Fig. 8). The moral is made explicit by the text Non Solus, "not on your own" (but in cooperation Schlüter \& Vinken 1997). In the beginning of the $19^{\text {th }}$ century the poet Ludwig Uhland, in his action against the autocracy of German rulers gave it a political twist: "Des Fürsten und des Volkes Rechte sind verwoben, wie sich Ulm' und Reb' umschlingen" (exhaustive treatment of the metaphor in Hagonow 1972 and in Demetz 1985).

But the most radical interpretation of the symbol was given in early Christianity in the Book of the Shepherd, written by Hermas, probably the brother of pope Pius I (Dibelius 1923). In Parable 2, the book starts describing the practical advantages and the amazing fruitfulness that is caused by this symbiosis of elm and grapevine. It even gives an additional biological explanation for that success: in dry periods, the elm would feed the vine with its own sap (that suits his later argumentation only too well, but according to recent research it is not entirely impossible - Horton \& Hart 1998). Hermas develops this into a model of the social organization, of the ideal relation and even the symbiosis between the rich and the poor in society: "the prayers of the poor are very powerful, as these poor are close to God. Therefore, they should also pray for the rich to help them to increase their wealth. The rich on the other hand, who by their focus on profit are distanced from God, should give to the poor what these need". This model of a Christian society based on mutual support was popular with several church fathers, who then regarded the Book of the Shepherd as a part of the Holy Scripture. But a couple of centuries later the church fathers decided to leave it out of the canon, so that the symbol of the marriage between elm and vine is lost for the bible.

So, the picture up to now seems simple: above the Alps a female elm delivers milk and some additional services; in the Mediterranean a male elm produces wine, marriage and cooperation. But truth is more complicated. Back to the farmer. He has to prune his elms once or twice a year to make room for the vine, its leaves and its fruits, to get them light and sun. Columella does not discuss pruning, but in another section of his handbook he tells us that all summer long, from June till October, the cattle is fed with tree leaves, while in winter leaf hay is part of their diet. So, the loppings from the elms were needed for the cattle! The importance of this use, even in the XX century, was made clear to me by a remark by Christine Buisman in 1935: "the preference for the supporting tree species depends on the livestock: in Emilia, where the farmers have cattle, they use the elm; in Tuscany, where they keep no cattle, they use the field maple as a support!" (Now we can also see what is wrong in the logo of Elsevier: the tree, the $\mathrm{elm}$, is not pruned! That would badly reduce its yield of grapes, and it negates its fodderfunction). So, even here, the elm had to produce milk, next to wine. This is also shown by the fact that in the area around Arbia,
Tuscany, where no wine is produced, some farmers kept a few pollarded elms to feed their domestic livestock. A remnant, grafted tree of that kind represents a remarkable specialized cultivar with an abundance of very large leaves in a dense crown, suggesting that this local use was old and important enough to generate such a highly useful cultivar, which I call Ulmus $x$ hollandica "Arbia". It is a cultural heritage which needs to be saved and propagated. Herbarium material will be deposited.

Now I dare to speculate on the origin of the "Atinia" and thus of the English elm. It is bound to have a history, any cultivar has a history: at some moment people must have recognized its special properties which made it worthwhile to be propagated. As a plant breeder, that is a person who wants to produce new cultivars, I wonder how this has happened. I suspect it has taken place in the eastern Mediterranean, as various similar soft-hairy elms occur there, roughly in the area between Austria and Israel, including Greece and probably also at the other side of the Aegean Sea, in present-day Turkey (a traveler told me that he had seen the Sultana grape being grown there high in elms. Could that be "Atinia"). Now what are the distinctive properties of the "Atinia"?

First of all its female sterility: in nature that is a very negative property against which natural selection will act. Individuals with this property will be very rare. Hardly a property that invites propagation as a cultivar.

Second, its ability to serve as a support for the grapevine - that is a true, but not an exceptional property - other trees like poplar will do the same job. The practice of leading the vine up into a tree (any tree) seems to have been well-known in the old Greece, though the agricultural handbooks, in which this practice may have been described, have not survived, as mentioned earlier.

Third, its value as fodder. This may be a serious candidate. We know that cattle love the "Atinia". Columella reports that they prefer it over the common field elm. A good farmer will notice that. It is even thinkable that the female sterility is an advantage here: the tree does not loose energy by producing seed, it can use all its energy in making leaves. And once the farmer propagates the tree for its fodder he can just as well use it as a prop for his vines too, combining the two functions. The fast growth of the elm and its tolerance of widely different soil conditions were a bonus, an extra reason for its use.

\section{Conclusion}

The elm owes its career in the Mediterranean to its assist in the production of wine, but only in combination with its general "milk"-function, the feeding of livestock. That justifies the title of this paper: "The elm, tree of milk and wine". 


\section{References}

Brockmann-Jerosch H (1936). Futterlaubbäume und Speiselaubbäume [Fodder trees and edible foliage trees]. Berichte der Schweizerischen Botanischen Gesellschaft 46: 594-613. [in German] De Vries J (1961). Altnordisches etymologisches Wörterbuch [Old Norse etymological dictionary]. Brill, Leiden, The Netherlands. [in Gerrman] Demetz P (1985). The elm and the vine: notes towards the history of a marriage topos. Proceedings of the Modern Language Association of America 73 (5): 521-532. - doi: 10.2307/460295 Dibelius M (1923). Die apostolischen Väter [The Apostolic Fathers]. Der Hirt des Hermas. Mohr, Tübingen, Germany. [in German]

Fuentes-Utrilla P, López-Rodrigues RA, Gil L (2004). The historical relationship of elms and vines. Investigación agraria. Sistemas y recursos forestales 13 (1): 7-15. [online] URL: http://revistas.inia.es/index.php/fs/article/view/808

Gil L, Fuentes-Utrilla P, Soto A, Cervera MT, Collada C (2004). English elm is a 2,000-yearold Roman clone. Nature 431: 1053. - doi: 10.10 38/4311053a

Haas JH, Rasmussen P (1993). Zur Geschichte der Schneitel- und Laubfutterwirtschaft in der Schweiz [On the history of pollarding and foliagefodder utilization in Switzerland]. Festschrift Zoller, Dissertationes Botanicae 196: 469-489. [in German]

Hagonow G (1972). Rebe und Ulme. Geschichte eines literarischen Bildes [Vine and elm. History of a literary image]. Schriften zur Weingeschichte nr. 28. Gesellschaft für Geschichte des
Weines, Wiesbaden, Germany. [in German] Heybroek HM (1963). Diseases and lopping for fodder as possible causes of a prehistoric decline of Ulmus. Acta Botanica Neerlandica 12 (1): 111. - doi: 10.1111/j.1438-8677.1963.tb00100.x Heybroek HM, Goudzwaard L, Kaljee H (2009). Iep of Olm, Karakterboom van de Lage Landen [Iep or Elm, a tree characteristic of the Low Countries]. KNNV Uitgeverij, Zeist, The Netherlands. [in Dutch]

Hoeg OA (1953). Treslag og tabu i Norge [Wood and taboo in Norway]. H. Aschehoug \& Co., Oslo, Norway. [in Norwegian]

Horton JL, Hart SC (1998). Hydraulic lift: a potentially important ecosystem process. Trends in Ecology and Evolution 13 (6): 232-236. - doi: 10.1016/S0169-5347(98)01328-7

Landmark JT (1863). Almetræer [Elm trees]. Tidsskrift for det praktiske Landbrug 1: 79-84. [in Danish/Norwegian]

Machatscheck M (2002). Laubgeschichten. Gebrauchswissen einer alten Baumwirtschaft, Speise- und Futterlaubkultur [Foliage stories. Knowledge of an ancient tree economy, food and fodder culture]. Böhlau Verlag, Wien, Köln, Weimar, Austria, Germany. [in German]

Nordhagen R (1954). Ethnobotanical studies on barkbread and the employment of wych elm under natural husbandry. Danmarks Geologiske Undersøgelse II, Række 80: 262-308.

Pässler J (1893). Untersuchungen über den Futterwerth der Blätter, Triebe und schwächsten Zweige verschiedener Laub- und Nadelhölzer, sowie einiger andrer Waldgewächse [Studies on the nutritive value of leaves, shoots and weakest branches of various deciduous and coniferous trees, as well as of some other woodland species]. Tharandter forstliches Jahrbuch 43: 212252. [in German]

Petrovic DS (1936). Die Bedeutung und Einrichtung der Futterlaubwälder [The importance and establishment of leaf-fodder forests]. In: Proceedings of the "IIe Congrès International de Sylviculture". Budapest (Hungary) 1936, vol. II, pp. 510-515. [in German]

Ropeid A (1960). Skav. Ein studie i eldre tids fôrproblem [Shavings. A study on the fodder problem in ancient time]. Universitetsforlaget, Oslo/ Bergen, Norway, pp. 1-387. [in Norwegian]

Russell EC (1947). The chemistry and digestibility of fodder trees and shrubs. In: "The use and misuse of shrubs and trees as fodder". Joint Publication no. 10, Imperial Agricultural Bureaux, Aberystwyth, UK, pp. 185-231.

Schlüter L, Vinken P (1997). The Elsevier Non Solus Imprint. Elsevier Science, Amsterdam, The Netherlands.

Trier J (1963). Venus. Etymologien um das Futterlaub [Venus. Etymologies around the leaf-fodder]. Ed. Böhlau, Köln/Graz, Germany/Austria. [in German]

Troels-Smith J (1960). Ivy, mistletoe and elm: Climatic indicators - fodder plants. Danmarks Geologiske Undersøgelse IV, 4: 1-32.

Woodman HE (1945). The composition and nutritive value of feeding stuffs. Bulletin 124, Ministry of Agriculture and Fisheries, London, UK. 